\title{
CLINICALLY RELEVANT LONG-TERM RELIABILITY OF CONTRALATERAL SUPPRESSION OF CLICK- EVOKED OTOACOUSTIC EMISSIONS
}

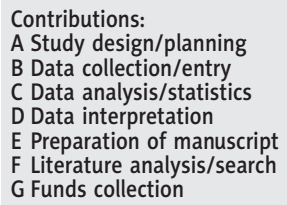

\author{
Edward C. Killan ${ }^{1 A B C D E F}$, Ruth E. Brooke ${ }^{1 A B E}$, Alexandra Farrell ${ }^{2 A B}$, \\ Jessica Merrett ${ }^{2 A B}$ \\ ${ }^{1}$ LICAMM, University of Leeds, Leeds, U.K. \\ ${ }^{2}$ Department of Audiology, Bradford Royal Infirmary, Bradford, U.K.
}

Corresponding author: Edward C. Killan, LICAMM, Faculty of Medicine and Health, University of Leeds, Woodhouse Lane, Leeds, U.K., LS2 9UT, e-mail: e.killan@leeds.ac.uk

\begin{abstract}
Background: Contralateral suppression of click-evoked otoacoustic emissions (CEOAEs) is a potentially useful clinical tool. Recent studies have provided descriptions of the reliability of this measure. In terms of their clinical relevance, the studies were limited as they utilised custom-built measurement systems or were conducted by a single tester over a short time. Further, previous studies generally reported only group data. The present study addresses these limitations by reporting individual and group data collected by two testers, using standard clinical equipment over longer time-frames.
\end{abstract}

Material and methods: Contralateral suppression of CEOAEs was recorded from 12 ears using the ILO 292 system. Clicks and contralateral broadband noise (BBN) were presented at $60 \mathrm{~dB}$ p.e. SPL and $65 \mathrm{~dB}$ SPL respectively. Global and best half-octave band suppression values (in $\mathrm{dB}$ ) were measured on four separate occasions by two testers spanning an average period of 35.5 days. Reliability was assessed via the intraclass correlation coefficient (ICC) and the standard error of measurement (SEm). Multilevel regression analysis was used to explore potential causes of variation in suppression.

Results: Global suppression reliability was shown to be worse than previous reports, with only fair to good reliability observed. ICC and SEm values were 0.57 and $0.47 \mathrm{~dB}$ respectively. Corresponding values for best half-octave band suppression were 0.49 and $0.64 \mathrm{~dB}$. Further analysis revealed no significant effect on contralateral suppression for a range of variables tested. Substantial variation (up to $2 \mathrm{~dB}$ ) in contralateral suppression between test sessions was seen for individual subjects.

Conclusions: Findings suggest that contralateral suppression of CEOAEs, measured by separate testers using standard clinical equipment, is not reliable over long time periods.

Keywords: click-evoked otoacoustic emission $\bullet \mathrm{CEOAE} \bullet$ contralateral suppression • reliability

\section{FIABILIDAD A LARGO PLAZO CON IMPORTANCIA CLIINICA DE LA SUPRESIÓN CONTRA-LATERAL DE LAS EMISIONES OTOACÚSTICAS EVOCADAS POR CLICKS}

\section{Resumen}

Introducción: La supresión contralateral de las emisiones otoacústicas evocadas por clicks (CEOAE) constituye una herramienta clínica potencialmente útil. Los estudios recientes describen la credibilidad de dicho método de medición. Dichos estudios están sin embargo limitados en cuanto a la utilidad clínica, ya que usaban sistemas de medición no estándar o bien las realizaba un solo investigador en un periodo de tiempo corto. Además, los estudios anteriores usaban por lo general únicamente datos grupales. En el estudio presente, se han tomado en cuenta dichas limitaciones, alegando a datos tanto individuales como grupales, provenientes de periodos de tiempo mas largos. Estos datos se han recogido por dos investigadores, utilizando dispositivos clínicos estándar.

Materiales y métodos: La supresión contralateral de las CEOAE se midió en 12 oídos, utilizando el sistema ILO 292. Clicks o ruido de banda ancha (BBN) fueron aplicados de forma contralateral al nivel de $60 \mathrm{~dB}$ p.e. SPL y $65 \mathrm{~dB}$ SPL, respectivamente. Los dos investigadores mencionados midieron cuatro veces los valores globales y los mejores valores de media octava de la supresión (en dB), sin embargo cada medición se realizó de forma independiente, con un intervalo medio de 35,5 días. La fiabilidad se evaluó en base al coeficiente de correlación intraclase (ICC) y el error estándar de medida (SEm). Para profundizar los posibles motivos de las diferencias de supresión se empleó el análisis de regresión multinivel.

Resultados: Se ha observado que la fiabilidad del valor de supresión global era menor que en los estudios anteriores y encajaba solo en el rango entre moderada a buena. Los valores de ICC y SEm eran de 0,57 y 0,47 dB, respectivamente. Los valores análogos de dichos indicadores para los mejores valores de media octava de la supresión eran de 0,49 y $0,64 \mathrm{~dB}$, respectivamente. A lo largo del análisis se ha demostrado que no hay una influencia importante sobre la supresión contralateral en el ámbito de las variables examinadas. En algunos casos, se ha observado una diferencia de supresión contralateral importante (de hasta $2 \mathrm{~dB}$ ) entre las distintas sesiones de medición. 
Conclusiones: Los resultados sugieren que la supresión contralateral de las CEOAE medida por varios investigadores y utilizando dispositivos clínicos estándar no demuestra fiabilidad a largo plazo.

Palabras clave: emisión otoacústica evocada por clicks • CEOAE • supresión contralateral • fiabilidad

\section{КЛИНИЧЕСКИ СУЩЕСТВЕННАЯ, ДОЛГОСРОЧНАЯ ДОСТОВЕРНОСТЬ КОНТРАЛАТЕРАЛЬНОГО ЗАГЛУШЕНИЯ ОТОАКУСТИЧЕСКОЙ ЭМИССИИ, ВЫЗВАННОЙ ЩЕЛЧКАМИ}

\section{Изложение}

Введение: Контралатеральное заглушение отоакустической эмиссии, вызванной щелчками (СЕОА1Е), является потенциально полезным клиническим инструментом. Последние исследования описывают достоверность этого измерения. В контексте клинической полезности данные исследования были ограничены, поскольку в них использовались нестандартные измерительные системы или их проводил только один исследователь в короткие сроки. Кроме того, более ранние исследования использовали, как правило, исключительно групповые данные. В настоящем исследовании отмечены вышеуказанные ограничения, с указанием индивидуальных и групповых данных, полученных за длительные временные промежутки. Эти данные были собраны двумя исследователями с использованием стандартного клинического оборудования.

Материал и методы: Контралатеральное заглушение CEOAЕ была измерена в 12 ушах с использованием системы ILO 292. Щелчки и широполосный шум (BBN) подавались контралатерально на уровне соответственно 60 дБ р.е. SPL и 65 дБ SPL. Два указанных исследователя четыре раза измерили глобальные значения и лучшие полуоктавные значения заглушения (в дБ), причём каждое измерение проводилось независимо, со средними промежутками 35,5 дней. Достоверность оценивалась на основании внутриклассового коэффициента корелляции (ICC) и стандартной ошибки измерения (SEm). Чтобы изучить вероятные причины различий заглушения, использовался многоуровневый анализ регрессии.

Результаты: Было обнаружено, что достоверность глобального значения заглушения была ниже, чем в более ранних работах, и находилась в диапазоне только от умеренной до хорошей. Значения ICC и SEm составляли соответственно 0,57 и 0,47 дБ. Аналогично значения этих показателей для лучших полуоктавных значений заглушения составляли 0,49 и 0,64 дБ. В процессе дальнейшего анализа было обнаружено отсутствие существенного влияния на контралатеральную супрессию в области исследовавшихся переменных. В некоторых случаях была обнаружена существенная разница (до 2 дБ) контралатерального заглушения между отдельными измерительными сессиями.

Выводы: Полученные результаты позволяют сделать вывод, что контралатеральное заглушение СЕОАЕ, измеряемое разными исследователями с помощью стандартного медицинского оборудования не показывает долгосрочную достоверность. Ключевые слова: отоакустическая эмиссия • вызванная щелчками • СЕОАЕ • контралатеральное заглушение • достоверность

\section{KLINICZNIE ISTOTNA, DŁUGOTERMINOWA WIARYGODNOŚĆ SUPRESJI KONTRALATERALNEJ EMISJI OTOAKUSTYCZNYCH WYWOŁANYCH TRZASKIEM}

\section{Streszczenie}

Wprowadzenie: Supresja kontralateralna emisji otoakustycznych wywołanych trzaskiem (CEOAE) jest potencjalnie przydatnym narzędziem klinicznym. Ostatnie badania opisują wiarygodność tego pomiaru. W kontekście przydatności klinicznej badania te były ograniczone, ponieważ wykorzystywano w nich niestandardowe systemy pomiarowe, bądź przeprowadzał je tylko jeden badacz w krótkim czasie. Ponadto, wcześniejsze badania wykorzystywały na ogół wyłacznie dane grupowe. W niniejszym badaniu odniesiono się do powyższych ograniczeń, przywołując dane indywidualne i grupowe, pochodzące z dłuższych odcinków czasowych. Dane te zostały zgromadzone przez dwóch badaczy z wykorzystaniem standardowego sprzętu klinicznego.

Materiał i metody: Supresję kontralateralną CEOAE zmierzono w 12 uszach, używając systemu ILO 292. Trzaski oraz szum szerokopasmowy (BBN) podawano kontralateralnie na poziomie odpowiednio $60 \mathrm{~dB}$ p.e. SPL oraz $65 \mathrm{~dB}$ SPL. Wymienieni dwaj badacze czterokrotnie zmierzyli wartości globalne i najlepsze wartości półoktawowe supresji (w dB), przy czym każdy pomiar przeprowadzano niezależnie, w odstępach średnio 35,5 dni. Wiarygodność oceniono na podstawie współczynnika korelacji wewnątrzklasowej (ICC) oraz standardowego błędu pomiaru (SEm). Aby zgłębić prawdopodobne przyczyny różnic supresji, wykorzystano wielopoziomową analizę regresji.

Wyniki: Zaobserwowano, iż wiarygodność wartości globalnej supresji była niższa niż w poprzednich doniesieniach oraz mieściła się w przedziale tylko od umiarkowanej do dobrej. Wartości ICC i SEm wynosiły odpowiednio 0,57 oraz 0,47 dB. Analogiczne wartości tych wskaźników dla najlepszych wartości półoktawowych supresji wynosiły 0,49 oraz 0,64 dB. W toku dalszej analizy wykazano brak istotnego wpływu na supresję kontralateralną w zakresie badanych zmiennych. W niektórych przypadkach zaobserwowano istotną różnicę (do $2 \mathrm{~dB})$ supresji kontralateralnej między poszczególnymi sesjami pomiarowymi.

Wnioski: Wyniki sugerują, iż supresja kontralateralna CEOAE mierzona przez różnych badaczy przy pomocy standardowego sprzętu medycznego nie wykazuje długoterminowej wiarygodności.

Słowa kluczowe: emisja otoakustyczna wywołana trzaskiem • CEOAE • supresja kontralateralna • wiarygodność 


\section{Introduction}

The presence of click-evoked otoacoustic emissions (CEOAEs) in normal hearing ears is well established [1-3]. CEOAEs are used widely in the clinical setting as an objective measure of cochlear function [2,3], and commercial equipment is available for this purpose, such as the ILO 292 system (Otodynamics Ltd, London, UK). CEOAE amplitude can be reduced (suppressed) by stimulation of the contralateral ear by broadband noise (BBN) [4-6]. This contralateral suppression of CEOAEs is possible due to the medial olivocochlear (MOC) system that provides a neural pathway from the brainstem to the outer hair cells within the cochlea [7-10]. The ILO 292 is also able to measure contralateral suppression of CEOAEs and is used in clinical settings for this purpose.

Potential roles suggested for the MOC system include enhancing auditory perception in noise $[11,12]$, auditory plasticity $[13,14]$, selective auditory attention [15-17], and providing protection against acoustic trauma [18]. Further, impaired MOC function has been reported in cases of auditory neuropathy [19], auditory processing disorders [20], tinnitus [21], learning disability, and autism $[22,23]$.Thus there is significant diagnostic potential for contralateral suppression of CEOAEs to be used as a measure of the MOC system. In addition, monitoring applications of contralateral suppression of CEOAEs have been proposed. For example, authors have suggested contralateral suppression could be used to detect and monitor physiological changes due to mild head injury [21,24], exposure to neuro-toxic chemical agents [25], or as a result of auditory training $[13,14]$.

In order for these potential applications to be successful in a clinical setting, it is necessary that contralateral suppression of CEOAEs is a repeatable measure. Specific to monitoring applications, it is necessary that contralateral suppression is stable (in the absence of physiological changes to the MOC system) over relatively long time periods, i.e. several weeks. It is possible that changes to subject-related factors such as middle ear status or CEOAE characteristics could lead to significant variation in the amount of contralateral suppression observed from test to test. Environmental factors, such as noise exposure and drug use, might also contribute to instability of the measurement. It is also necessary that contralateral suppression of CEOAEs is reliable across different testers. Differences in probe-fitting technique between testers could result in variation in click and BBN spectra and level that in turn lead to variable suppression measurements. It is also desirable to understand reliability at both the subject and group level, and for equipment and metrics that are used widely in clinical settings.

Previous authors have reported reliability data for contralateral suppression of CEOAEs. However, a number used custom measurement equipment that would not typically be used in a clinical setting. Using such equipment, de Boer and Thornton [13] described data from a study investigating auditory learning and MOC activity that were held to show stable contralateral suppression of CEOAEs over time. However, measurements were made by a single tester only over a short time period of 4 days. Further, no conventional measure of reliability or individual subject data was reported. Marshall et al. [26] used non-standard equipment to obtain estimates of the reliability of contralateral suppression measures for chirp-evoked otoacoustic emissions. Again, measurements were made over a short time period (typically 1 day) and by a single tester, and as such are limited in terms of their clinical relevance. Further, contralateral suppression was reported as a complex estimate of MOC reflex strength (\%). While more complex metrics may provide more accurate estimates of the activity of the MOC $[12,26,27]$, they are less likely to be used in a clinical setting where the simple difference (in $\mathrm{dB}$ ) between CEOAE recordings is typically used. Reliability of contralateral suppression was estimated from group data by the standard error of measurement (SEm). Results indicated "good" reliability, with a SEm of 3.8\% (in comparison to median contralateral suppression of $41 \%)$. Mertes and Goodman [28] also used custom-built equipment to study changes in CEOAE contralateral suppression, with measurements in their study made over a period of up to 35 days. However, less relevant to the clinical setting, contralateral suppression was calculated as a complex quantity that took into account magnitude and phase changes, and all measurements were made by a single tester. Similar to the previous studies, Mertes and Goodman found high levels of reliability at the group level, with Cronbach's a typically greater than 0.8 . In contrast to other studies, they also reported within-subject data that demonstrated substantial variability. They therefore concluded that changes as large as $2 \mathrm{~dB}$ would be needed to be certain that a change in suppression was caused by a particular pathology. Finally, Mishra and Lutman [29] reported a detailed reliability study in which CEOAEs were recorded using the ILO 292 while a customised set-up was used to deliver BBN. All measurements were made by a single tester on two occasions separated by up to 4 days. Reliability of contralateral suppression (in $\mathrm{dB}$ ) was estimated using Cronbach's a which indicated good reliability across subjects $(\alpha=0.8)$. Variation at the individual subject level was not specifically described, although Bland-Altman plots showed individual differences between tests ranging from near zero to over $1 \mathrm{~dB}$.

Other studies have reported contralateral suppression reliability data obtained using the clinically used ILO system. In the first of these studies, Graham and Hazell [30] used the Otodynamics ILO 92 (a precursor of the ILO 292 system). They obtained three measurements of suppression (in $\mathrm{dB}$ ) over a 42 day period. Measurements were described as being "relatively stable" over time, although, consistent with the findings of Mertes and Goodman [28], substantial variations in suppression levels were seen within individual subjects. However, the study was limited by measurements being made by a single tester from only five normally hearing subjects. Further, other important details, such as the subjects' CEOAE signal-to-noise ratio (SNR) and standard measures of reliability, were not reported. More recently, Stuart and Cobb [31] provided estimates of CEOAE contralateral suppression measured using the default settings of the ILO 292 system. Cronbach's $\alpha$ values greater than 0.9 were obtained, indicating excellent reliability for suppression measured over 2 days, although again only a single tester was used. Visual inspection of their Bland-Altman plots reveal individual 
Table 1. Mean, minimum, and maximum interval (days) between test sessions

\begin{tabular}{cccc}
\hline & & Duration (days) & Maximum \\
\cline { 2 - 4 } Interval & Mean & Minimum & 29 \\
\hline$T_{1}-T_{2}$ & 11.2 & 5 & 34 \\
\hline$T_{2}-T_{3}$ & 13.3 & 3 & 25 \\
\hline$T_{3}-T_{4}$ & 11.0 & 7 & 56 \\
\hline$T_{1}-T_{4}$ & 35.5 & 17 & 25 \\
\hline
\end{tabular}

differences in suppression as large as approximately 1.3 dB. Similarly, good reliability has been demonstrated by Jedrzejczak et al. [32] who obtained SEm values of the order of $0.2 \mathrm{~dB}$ (compared to mean suppression of approximately $1 \mathrm{~dB}$ ). However, these measurements were made only hours apart by a single tester using the ILO 292 system, and unlike Stuart and Cobb [31], no individual subject data were presented.

Thus, to date no single study has reported clinically relevant reliability data for contralateral suppression of CEOAEs. The aim of the present study was therefore to provide a clinically-relevant description of contralateral suppression of CEOAE reliability. This was achieved by two separate testers measuring contralateral suppression (in $\mathrm{dB}$ ) using the ILO 292 system over relatively long time frames. It has been suggested that contralateral suppression measured within a narrow frequency band, where CEOAE SNR is optimal, might provide information about MOC physiology in ears where overall CEOAE SNR is less than optimal and suppression measures would be limited by noise-floor effects [33]. Therefore, reliability was explored for wideband and within best-frequency bands. Finally, unlike previous studies that have utilised standard equipment, data will be reported at the group and individual subject level.

\section{Material and methods}

Subjects were 12 otologically normal adults (7 female, 5 male), aged $21-39$ years (median $=28.5$ years). All subjects had audiometric thresholds of $20 \mathrm{~dB}$ HL or better from 0.25 to $8 \mathrm{kHz}$ (as measured using a Frye FA12 audiometer), normal middle ear function (as measured by a Kamplex KT20 tympanometer), and repeatable CEOAEs (i.e. SNR $>6 \mathrm{~dB}$ and $>70 \%$ reproducibility as reported by the ILO 292) in response to linearly presented $60 \mathrm{~dB}$ p.e. SPL clicks. Subjects were found to have no spontaneous otoacoustic emissions as measured by the ILO 292 system. Previous studies have indicated that properties of CEOAEs (including contralateral suppression) are similar between left and right ears of an individual subject $[34,35]$, and that there is no ear effect on the variation of contralateral suppression over time [30]. Therefore, to obtain an independent data-set, suppression was measured for CEOAEs recorded from the right ear only of each subject. All subjects gave informed written consent in accordance with the requirements of the local ethics committee (project number SHREC/RP/449).

All contralateral suppression of CEOAE measurements were made using the ILO 292 system. Measurements were made using its standard protocol. This involves recording a CEOAE while BBN is automatically switched on $(\mathrm{BBN}+)$ and off (BBN-) every 3 seconds in the contralateral ear. CEOAEs were averaged separately (260 sweeps above the noise rejection level of $46 \mathrm{~dB}$ ) for the $\mathrm{BBN}+$ and $\mathrm{BBN}-$ conditions, and suppression was defined (as reported by the software) as the difference between the level of the $\mathrm{CEOAEs}$ for the $\mathrm{BBN}-$ and $\mathrm{BBN}+$ conditions. Clicks were presented in the linear mode (i.e. all clicks were presented with equal phase and amplitude) at $60 \mathrm{~dB}$ p.e. SPL and at the default presentation rate of $50 / \mathrm{s}$ via an Otodynamics measurement probe. The linear mode was used as it preserves both the linear and nonlinear components of suppression [33], and at $60 \mathrm{~dB}$ p.e. SPL contamination of the CEOAE by stimulus artefact is considered minimal. Broadband noise was presented at $65 \mathrm{~dB}$ SPL via a second Otodynamics measurement probe.

Subjects were required to attend four test sessions $\left(T_{1}, T_{2}\right.$, $\mathrm{T}_{3}$, and $\mathrm{T}_{4}$ ). Table 1 shows the mean (and minimum and maximum) number of days between test sessions across all subjects. Subjects were asked to avoid excessive noise exposure during the 24 hours prior to attending each test session. At the start of each session otoscopy was used to confirm no visible abnormalities, and middle ear compliance and pressure were measured using $226 \mathrm{~Hz}$ tympanometry. Although hearing thresholds were obtained at $\mathrm{T}_{1}$, at $\mathrm{T}_{2}, \mathrm{~T}_{3}$, and $\mathrm{T}_{4}$ subjects self-reported any changes in hearing thresholds. Following this, both measurement probes were fitted into the subject's ear canals and probe fit integrity was verified using the 'check-fit' facility of the ILO 292 measurement system. For each subject, the same sized probe tip was used at all four test sessions. Efforts were made to match click and BBN levels measured by the check-fit facility to those obtained at the previous test session. Fitting of measurement probes and subsequent recording of contralateral suppression was performed by one of two experienced audiologists. All subjects were tested at least once by each audiologist. All recordings took place within a sound-attenuated room. Click and BBN levels were monitored throughout each recording, and click stability, as reported by the ILO 292 system, was always greater than $90 \%$.

A number of studies have shown that attention can influence contralateral suppression of CEOAEs [15,36,37]. Therefore efforts were made to control subjects' attention via a reading task. Subjects were instructed to read a section of novel text and were told they would be required to answer questions regarding the text at the end of the recording. 
Table 2. Test variables used in the two-level random-intercept models of contralateral suppression of CEOAEs. For each variable the grand mean (and SD) and the corresponding change in model deviance, $\chi^{2}$, (and $p$ value) for global and best half-octave band suppression is shown

\begin{tabular}{|c|c|c|c|c|c|}
\hline \multirow[t]{3}{*}{ Variable } & \multirow{2}{*}{ Mean (SD) } & \multicolumn{4}{|c|}{$\begin{array}{c}\text { Change in model deviance, } \\
\chi^{2}(p \text { value })\end{array}$} \\
\hline & & \multicolumn{2}{|c|}{ Global } & \multicolumn{2}{|c|}{ Half-octave band } \\
\hline & - & 0.10 & $(0.75)$ & 0.20 & $(0.65)$ \\
\hline RE middle ear pressure (daPa) & $-10.4 \quad(25.1)$ & 1.22 & $(0.27)$ & 5.01 & $(0.03)$ \\
\hline RE middle ear compliance $(\mathrm{mL})$ & $0.6 \quad(0.2)$ & 0.05 & $(0.82)$ & 0.74 & $(0.40)$ \\
\hline LE middle ear pressure (daPa) & $-9.4 \quad(13.2)$ & 2.75 & $(0.10)$ & 0.00 & $(0.96)$ \\
\hline LE middle ear compliance (mL) & $0.6 \quad(0.2)$ & 0.13 & $(0.72)$ & 0.76 & $(0.38)$ \\
\hline Click stability (\%) & $96.7 \quad(4.6)$ & 0.62 & $(0.43)$ & 3.88 & $(0.05)$ \\
\hline Click level (dB p.e. SPL) & 60.2 & 0.31 & $(0.58)$ & 0.00 & $(0.96)$ \\
\hline BBN level (dB SPL) & 64.2 & 0.80 & $(0.37)$ & 0.60 & $(0.44)$ \\
\hline BBN relative level (dB) & $(2.0)$ & 0.69 & $(0.41)$ & 0.13 & $(0.72)$ \\
\hline Global CEOAE SNR (dB) & 11.5 & 0.37 & $(0.54)$ & 0.06 & $(0.81)$ \\
\hline
\end{tabular}

RE - right ear; LE - left ear; BBN relative level was calculated as the difference between BBN and click level.

In addition to global values, contralateral suppression was also measured in each subject's best half-octave frequency band. This was determined as the half-octave frequency band (centred at $1,1.4,2,2.8$, or $3 \mathrm{kHz}$ ) with the highest $\mathrm{SNR}$ for the CEOAE recorded in the $\mathrm{BBN}-$ condition. For each subject, the half-octave frequency band with highest SNR remained constant across all four test sessions. Reliability for global and best-band measures obtained at $\mathrm{T}_{1}$ and $\mathrm{T}_{4}$ was assessed using the intra-class correlation coefficient (ICC) calculated using a two-level random-intercept regression model $[38,39]$. Such models partition variance across the two levels (test session and subject), and the ICC is defined as the proportion of total variance within the model accounted for by variance at the subject level. It has been suggested that ICC $<0.4$ represents poor, $0.4<$ ICC $<0.75$ fair to good, and ICC $>0.75$ excellent reliability [27]. To allow comparison with previously reported descriptions of reliability, the standard error of measurement (SEm) was also calculated using the ICC values. Finally, a separate model was calculated to explore the effect of a number of test variables on contralateral suppression. These are given in Table 2. For this model, data from all four test sessions were used. All regression models were estimated using the maximum likelihood method via an iterative generalised least squares procedure, allowing an estimate of model deviance to be made. Changes in model deviance, as a result of the addition of test variables, were used as the test statistic $[38,39]$. This deviance statistic has a $\chi^{2}$ distribution with degrees of freedom equal to 1 . To allow for multiple hypotheses testing, a strict significance level of $p<0.01$ was used.

\section{Results}

Figure 1 shows global contralateral suppression of CEOAEs as a function of days post $\mathrm{T}_{1}$ (where $\mathrm{T}_{1}$ is day zero). Panel A shows mean suppression ( \pm 1 standard deviation,
SD) plotted as a function of the mean interval between test sessions $( \pm 1 \mathrm{SD})$. The figure shows that mean global contralateral suppression was stable over time, with only small differences between values. Mean suppression (SD) at $\mathrm{T}_{1}, \mathrm{~T}_{2}, \mathrm{~T}_{3}$, and $\mathrm{T}_{4}$ was $1.63 \mathrm{~dB}(0.60), 1.42 \mathrm{~dB}(0.72)$, $1.53 \mathrm{~dB}(0.57)$, and $1.58 \mathrm{~dB}(0.82)$ respectively. Panel $\mathrm{B}$ shows the individual subject data for all 12 subjects and is included here to demonstrate the substantial variability between test subjects observed at the individual subject level. Each subject is represented as a different colour. Inspection of panel B reveals large changes in suppression between consecutive test sessions for a number of subjects. This variation is more easily seen in Figure 2 which shows a histogram of the absolute differences in contralateral suppression between consecutive test sessions for all 12 subjects. While the histogram has a peak at $0.5 \mathrm{~dB}$, a number of differences were relatively large (as large as 1.8 $\mathrm{dB}$ ). Figure 3 shows the variability of suppression across all four test sessions for each subject ranked as a function of their global CEOAE SNR (lowest to highest). As indicated in the figure, CEOAE SNR ranged from 6.0 to 20.7 $\mathrm{dB}$. For each subject median, minimum, and maximum suppression is shown. Figure 3 shows a trend for variability in suppression to decrease, i.e. reliability to improve, with increasing SNR.

Reliability was assessed between test sessions $\mathrm{T}_{1}$ and $\mathrm{T}_{4}$ using ICC and SEm. As shown in Table 1, the mean difference between $\mathrm{T}_{1}$ and $\mathrm{T}_{4}$ was 35.5 days ( $\mathrm{min}=17$ days; $\max =56$ days). ICC calculated via a two-level random-intercept model was 0.57 , indicating fair to good reliability. The resultant SEm was $0.47 \mathrm{~dB}$. A second model, using data from all four test sessions, explored the effect of a number of within-subject variables on contralateral suppression. The grand means (and SD) for these variables and the results from the model are given in Table 2. Test variables were relatively stable over time and no significant effects 
A

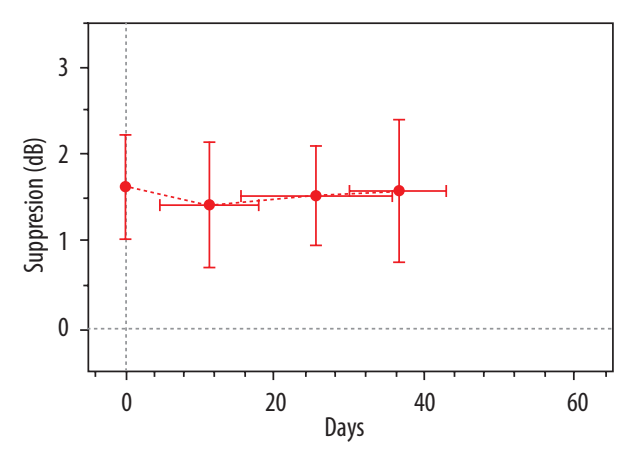

B

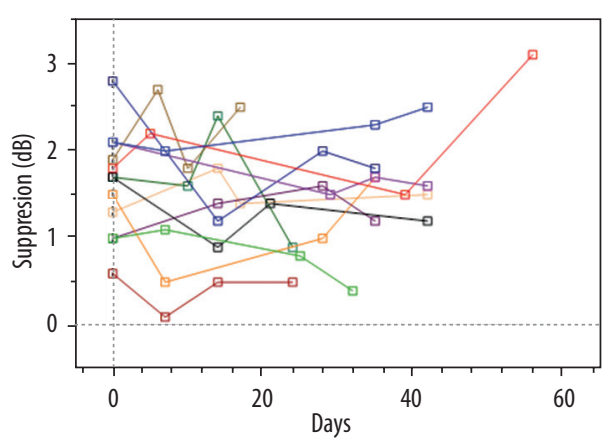

Figure 1. Global contralateral suppression of CEOAEs as a function of days post- $T_{1}$ (where $T_{1}$ is day zero). Panel A shows mean suppression. Vertical error bars represent \pm 1 SD and horizontal error bars represent \pm 1 SD of the mean time interval between test sessions. Panel B shows the results for each subject represented by a different colour. Squares represent test sessions $T_{1}$ to $T_{4}$

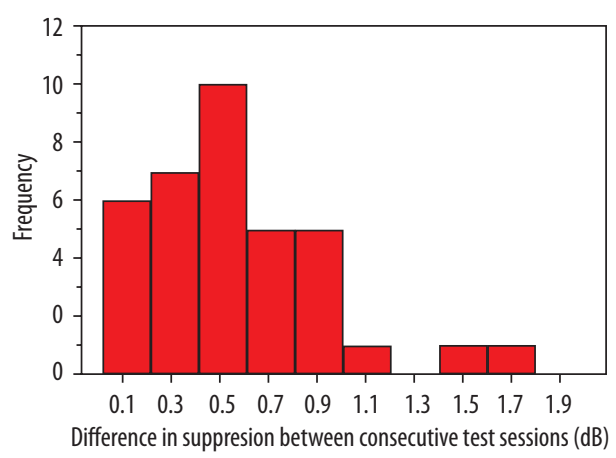

Figure 2. Histogram showing differences in global contralateral suppression of CEOAEs between consecutive test sessions

A

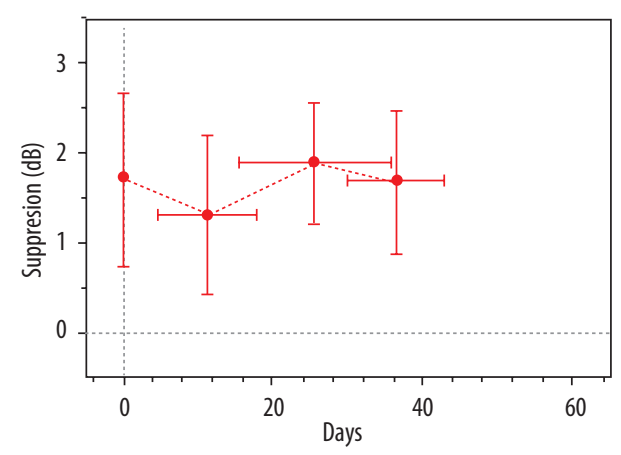

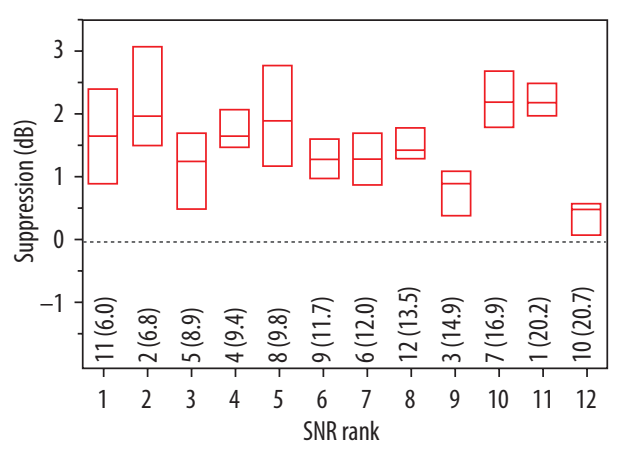

Figure 3. Within-subject variability of global CEOAE contralateral suppression across all four test sessions for each subject (ranked by SNR, lowest to highest). The lower and upper bounds of the blocks represent minimum and maximum suppression. Median suppression is represented as the horizontal line within each block. Subject number (and SNR) are given at each ranking

B

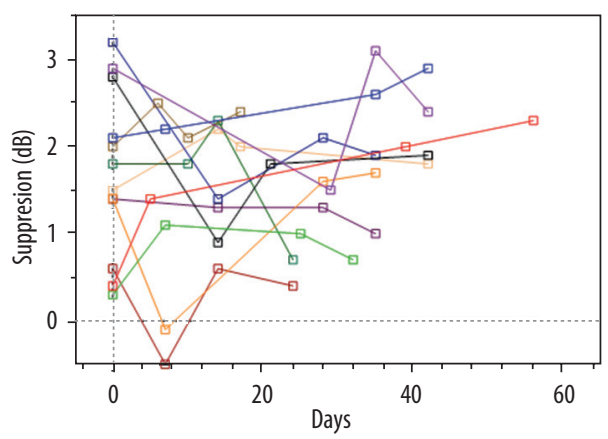

Figure 4. Contralateral suppression of CEOAEs measured within each subject's best half-octave frequency band as a function of days post- $T_{1}$ (where $T_{1}$ is day zero). The format is the same as Figure 1

were seen for all variables tested. Subject sex $\left(\chi^{2}=0.06\right.$, $\mathrm{df}=1, p=0.81)$ and age $\left.\chi^{2}=0.10, \mathrm{df}=1, p=0.75\right)$ were also shown to be non-significant.
Results were also obtained for subjects' best half-octave frequency band. For the majority of subjects $(n=8)$, the best half-octave band was centred at $1.4 \mathrm{kHz}$. A small number of subjects' best frequency band was centred at 1 and $2 \mathrm{kHz}$ ( $n=2$ and 2 respectively) with none at 2.8 or $4 \mathrm{kHz}$. 


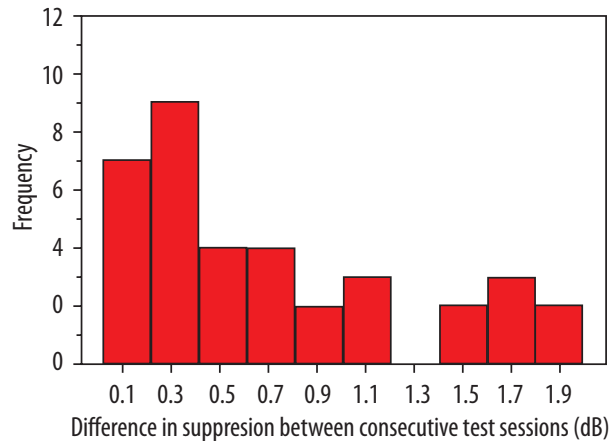

Figure 5. Histogram of differences in best half-octave band contralateral suppression of CEOAEs between consecutive test sessions

Figure 4 shows contralateral suppression measured within each subject's best half-octave frequency band as a function of time. The format is the same as that for Figure 1, with panel A showing mean suppression $( \pm 1 \mathrm{SD})$. Greater variability between tests is seen in comparison to global suppression. Mean best-band suppression at $\mathrm{T}_{1}, \mathrm{~T}_{2}, \mathrm{~T}_{3}$, and $\mathrm{T}_{4}$ was $1.70 \mathrm{~dB}(0.97), 1.31 \mathrm{~dB}(0.89), 1.88 \mathrm{~dB}(0.68)$, and $1.68 \mathrm{~dB}(0.80)$ respectively. Panel $\mathrm{B}$ reveals that, as was the case for global measures, contralateral suppression had substantial variation within-subjects. For two subjects, negative values of suppression were obtained, indicating enhancement of the CEOAE response. Figure 5 shows a histogram of the differences in contralateral suppression. While the histogram shows the most frequent difference to be reasonably small (around $0.3 \mathrm{~dB}$ ), a broad spread of differences, up to $1.9 \mathrm{~dB}$, was observed.

For all subjects, higher CEOAE SNRs were seen within individual half-octave frequency bands compared to the global condition, with values ranging between 13.1 and $25.3 \mathrm{~dB}$ ). Figure 6 shows the variability of suppression for each subject ranked by SNR (lowest to highest) within their best frequency band. Compared to the global measures, half-octave band contralateral suppression was more variable, with no obvious trend for variability to reduce with increasing SNR.

Contralateral suppression measured within the best halfoctave band at $\mathrm{T}_{1}$ and $\mathrm{T}_{4}$ had an ICC of 0.49 and SEm of $0.64 \mathrm{~dB}$, consistent with reliability being poorer than the global measure. A model of contralateral suppression across all four test sessions revealed no significant effect of within-subject test variables (see Table 2). Subject sex $\left(\chi^{2}=0.75, \mathrm{df}=1, p=0.39\right)$ and age $\left(\chi^{2}=1.09, \mathrm{df}=1, p=0.30\right)$ were also shown to be non-significant.

\section{Discussion}

Contralateral suppression of CEOAEs has numerous potential clinical applications in detecting and monitoring physiological changes to the MOC system [13,19-25]. For these clinical applications to be successful, it is necessary that contralateral suppression of CEOAEs measured by standard clinical equipment is stable over relatively long periods of time and across different testers. Further, it is important

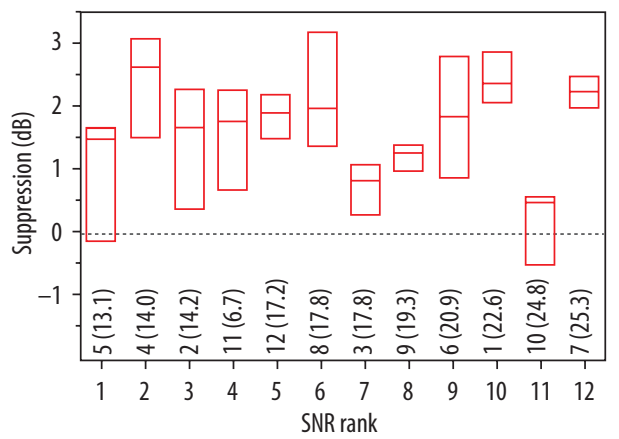

Figure 6. Within-subject variability of half-octave band CEOAE contralateral suppression across all four test sessions and for each subject (ranked by SNR, lowest to highest). The format is the same as Figure 3

to understand the variability of contralateral suppression within individuals, as well as at the group level. Previous studies have provided descriptions of the reliability of contralateral suppression of CEOAEs, however these are limited in terms of their relevance to the clinical setting. Data have been reported for customised, non-standard measurement equipment not typically used in the clinical setting $[26,28,29,36]$, and where clinical equipment has been used findings are limited by the use of one tester only and data being collected over short time-spans (typically less than 1 week) $[31,32]$. One previous study did report data obtained over a longer time span (42 days) [30], however only a single tester was used and important detail regarding the subjects' CEOAEs were not presented. In addition, none of the studies that used standard clinical equipment commented on the within-subject variability of contralateral suppression of CEOAEs. Therefore, the aim of this study was to provide a description of the reliability of contralateral suppression of CEOAEs relevant to the clinical setting, at the group and individual level. Contralateral suppression was measured by two independent testers using standard clinical equipment over substantially longer time frames than those typically reported by previous investigators.

Our findings for mean global contralateral suppression (around 1.5-1.6 dB) are broadly consistent with those previously reported by authors who also used the ILO 292 system and similar test parameters. Using the same click and BBN levels as our study ( $60 \mathrm{~dB}$ p.e. SPL and 65 dB SPL respectively), Stuart and Cobb [31] reported contralateral suppression ranging between approximately 0.1 and $1.9 \mathrm{~dB}$ with a mean of around $1 \mathrm{~dB}$. Similarly, Jedrzejczak et al. [32] reported mean contralateral suppression of approximately 0.9 , although they used click and BBN levels of $65 \mathrm{~dB}$ p.e. SPL and $60 \mathrm{~dB}$ SPL respectively. In terms of reliability, our data indicate fair to good reliability for global contralateral suppression at the group level for test intervals as long as 56 days. This is worse than the good to excellent reliability estimates described in the literature for shorter inter-test intervals using the ILO 292 system $[31,32]$ or other custom-built equipment $[26,28,29]$.

In addition, our findings demonstrated substantial within-subject variability (of the order of 1-2 dB) in global 
contralateral suppression. This is in keeping with findings from other studies. Mertes and Goodman [28] found within-subject changes in contralateral suppression of around $1.5 \mathrm{~dB}$. Though not specifically commented on, individual variability of similar magnitude is evident in Bland-Altman plots presented by other researchers [29,31]. These indicate within-subject differences up to $1.3 \mathrm{~dB}$. Our analysis of individual variability revealed a trend for subjects with lower CEOAE SNR to have more variable contralateral suppression than individuals with high CEOAE SNR. This is consistent with previously reported findings that suggested reliability of contralateral suppression of CEOAEs increases with increasing CEOAE SNR up to approximately $20 \mathrm{~dB}$ [26]. Presumably the higher levels of noise present in CEOAE recordings with lower SNRs result in higher within-subject variability.

It has previously been suggested that contralateral suppression measured within individual frequency bands, where CEOAE SNR is optimal, could be used as a proxy measure of MOC physiology in ears where overall CEOAE SNR is less than optimal [33]. For this reason, the reliability of contralateral suppression was estimated within a subject's best half-octave frequency band according to SNR. Consistent with previous research [26,32], higher mean levels of contralateral suppression were observed within a subject's best frequency band. Poorer reliability was observed within half-octave frequency bands both at the group and individual subject level, despite SNRs being higher than those obtained for global measures. This is at odds with the observation that global CEOAE suppression reliability improved with increasing SNR, presumably due to lower levels of noise in the recordings. Following this logic through, it would be reasonable to expect improved reliability of suppression would be observed within half-octave bands, where higher SNRs were measured. Further research is warranted to explore this issue. Analysis of best-band suppression at the individual level also revealed examples of BBN causing both suppression and enhancement of CEOAEs in consecutive test sessions. This is not a novel finding as contralateral enhancement of CEOAEs has been observed previously by a number of authors $[5,28,40]$.

A number of potential causes of variation in global and half-octave contralateral suppression were explored. It is possible that differences in the probe placement techniques of the two separate testers could account for variability in contralateral suppression. Differences in probe placement technique could lead to variability in click and BBN levels, which in turn could result in poor suppression reliability. However, click level and stability, and BBN absolute and relative levels, were shown to be stable across test sessions and statistical analysis revealed that tester, and click and BBN levels, were not significant factors. Small within-subject changes in middle ear function were observed between test sessions, although these were also shown not to have a significant effect on contralateral suppression. It is also possible that instability over time of the CEO$\mathrm{AE}$ response (in the absence of $\mathrm{BBN}$ ) could lead to variation in contralateral suppression. However, CEOAE SNR (a measure of CEOAE response) was shown to be stable across test sessions and did not have a significant effect on contralateral suppression. This is in keeping with previous reports that have shown CEOAEs to be highly repeatable over time $[32,41,42]$.

It is possible that other factors, not measured within this study, were responsible for the reduced reliability of contralateral suppression of CEOAEs. Both CEOAEs and their suppression are sensitive to noise exposure [43-45]. Whereas subjects were required to avoid exposure to loud noise 24 hours prior to a test session, there was no attempt to control or measure subjects' noise exposure at other times. Further, hearing thresholds were only formally measured at the first test session, with self-report of hearing relied upon at subsequent sessions. It is therefore possible that small changes in hearing sensitivity were present that could have accounted for suppression variability. Subjects' use of medication that may cause changes to the CEOAE response $[46,47]$ was also not recorded. A further limitation of the present study is that middle ear acoustic reflex thresholds were not measured. Most reports suggest typical thresholds for the acoustic reflex to be in the region of $70-80 \mathrm{~dB}$ SPL in normal hearing ears $[5,6,29,48]$. However, evidence has been reported which indicates that BBN at $65 \mathrm{~dB}$ SPL (i.e. the level used in the present study) can activate the middle ear reflex [27,33]. It is therefore possible that inconsistent activation of the middle ear reflex across test sessions affected the reliability of CEOAE contralateral suppression. It is also possible that the click rate used (50 clicks/s) activated the ipsilateral MOC system [49], thus potentially confounding the amount of suppression measured. Changes in subjects' attention state may also have been responsible for variability in CEOAE suppression. While this study made attempts to control subjects' attention via a simple reading-based activity, no formal quantification of subjects' attention across sessions was employed. The attention effect has been shown to be relatively small $[15,37]$, but it is a potential factor in the variability of suppression observed. Finally, it should be noted that the sample size of this study is relatively small, and as such the likelihood of finding a significant effect for the variables tested may have been limited.

\section{Conclusions}

The results from this study add to our understanding of the reliability of contralateral suppression of CEOAEs by describing a clinically relevant description of its changes over time. Contralateral suppression measurements were made on four separate occasions by two testers over a time period of several weeks. All measurements were made using standard equipment and default settings typically used in the clinical setting. Findings suggest that, at present, contralateral suppression of CEOAEs is not a reliable measure. Both group and individual subject data revealed substantial variation, such that large changes in suppression, of the order of 1-2 $\mathrm{dB}$, would be required to confidently attribute the change to specific pathology. This was the case for both global and best-band contralateral suppression. As such, the proposed use of contralateral suppression of CEOAEs as a tool for monitoring physiological changes within the MOC system is not supported. Future research should focus on methods to improve the reliability of this measure, such as ways to maximise CEOAE SNR, to allow extended clinical applications of contralateral suppression of CEOAEs. 
1. Kapadia S, Lutman ME. Are normal hearing thresholds a sufficient condition for click-evoked otoacoustic emissions? J Acoust Soc Am, 1997; 101(6): 3566-76.

2. Hall J. Handbook of Otoacoustic Emissions. 2000, San Diego: Singular.

3. Robinette MS, Glattke TJ. Otoacoustic Emissions: Clinical applications. 2002, New York: Thieme.

4. Collet L, Kemp DT, Veuillet E, Duclaux R, Moulin A, Morgon A. Effect of contralateral auditory stimuli on active cochlear micro-mechanical properties in human subjects. Hear Res, 1990; 43(2): 251-61.

5. Hood LJ, Berlin CI, Hurley A, Cecola RP, Bell B. Contralateral suppression of transient-evoked otoacoustic emissions in humans: Intensity effects. Hear Res, 1996; 101(1-2): 113-18.

6. Veuillet E, Collet L, Duclaux R. Effect of contralateral acoustic stimulation on active cochlear micromechanical properties in human subjects: Dependence on stimulus variables. J Neurophysiol, 1991; 65(3): 724-35.

7. Arnesen AR. Fibre population of the vestibulocochlear anastomosis in humans. Acta Oto-Laryngologica, 1984; 98(5-6): 501-18.

8. Elgoyhen AB, Katz E. The efferent medial olivocochlear-hair cell synapse. J Physiol, 2012; 106(1-2): 47-56.

9. Guinan JJ. Olivocochlear efferents: Anatomy, physiology, function, and the measurement of efferent effects in humans. Ear Hear, 2006; 27(6): 589-607.

10. Moore JK, Simmons DD, Guan Y. The human olivocochlear system: Organization and development. Audiol Neurootol, 1999; 4(6): 311-25.

11. De Boer J, Thornton AR, Krumbholz K. What is the role of the medial olivocochlear system in speech-in-noise processing? J Neurophysiol, 2012; 107(5): 1301-12.

12. Garinis A, Werner L, Abdala C. The relationship between MOC reflex and masked threshold. Hear Res, 2011; 282(1-2): 128-37.

13. De Boer J, Thornton ARD. Neural correlates of perceptual learning in the auditory brainstem: Efferent activity predicts and reflects improvement at a speech-in-noise discrimination task. J Neurosci, 2008; 28(19): 4929-37.

14. Veuillet E, Magnan A, Ecalle J, Thai-Van H, Collet L. Auditory processing disorder in children with reading disabilities: Effect of audiovisual training. Brain, 2007; 130(11): 2915-28.

15. Maison S, Micheyl C, Collet L. Influence of focused auditory attention on cochlear activity in humans. Psychophysiology, 2001; 38(1): 35-40.

16. Giard MH, Collet L, Bouchet P, Pernier J. Auditory selective attention in the human cochlea. Brain Res, 1994; 633(1-2): 353-56.

17. Giard MH, Fort A, Mouchetant-Rostaing Y, Pernier J. Neurophysiological mechanisms of auditory selective attention in humans. Front Biosci, 2000; 5: D84-94.

18. Rajan R. Centrifugal pathways protect hearing sensitivity at the cochlea in noisy environments that exacerbate the damage induced by loud sound. J Neurosci, 2000; 20(17): 6684-93.

19. Starr A, Picton TW, Sininger Y, Hood LJ, Berlin CI. Auditory neuropathy. Brain, 1996; 119(3): 741-53

20. Muchnik C, Ari-Even Roth D, Othman-Jebara R, Putter-Katz H, Shabtai EL, Hildesheimer M. Reduced medial olivocochlear bundle system function in children with auditory processing disorders. Audiol Neurootol, 2004; 9(2): 107-14.
21. Ceranic BJ, Prasher DK, Raglan E, Luxon LM. Tinnitus after head injury: evidence from otoacoustic emissions. J Neurol Neurosurg Psychiatry, 1998; 65(4): 523-29.

22. Khalfa S1, Bruneau N, Rogé B, Georgieff N, Veuillet E, Adrien JL et al. Peripheral auditory asymmetry in infantile autism. Eur J Neurosci, 2001; 13(3): 628-32.

23. Garinis AC, Glattke T, Cone-Wesson BK. TEOAE suppression in adults with learning disabilities. Int J Audiol, 2008; 47(10): 607-14.

24. Nolle C, Todt I, Seidl RO, Ernst A. Pathophysiological changes of the central auditory pathway after blunt trauma of the head. J Neurotraum, 2004; 21(3): 251-58.

25. Micarelli A, Viziano A, Genovesi G, Bruno E, Ottaviani F, Alessandrini M. Lack of contralateral suppression in transientevoked otoacoustic emissions in multiple chemical sensitivity: A clinical correlation study. Noise Health, 2016; 18(82): 143-49.

26. Marshall L, Lapsley Miller JA, Guinan JJ, Shera CA, Reed CM et al. Otoacoustic-emission-based medial-olivocochlear reflex assays for humans. J Acoust Soc Am, 2014; 136(5): 2697-713.

27. Guinan JJ, Backus BC, Lilaonitkul W, Aharonson V. Medial olivocochlear efferent reflex in humans: Otoacoustic emission (OAE) measurement issues and the advantages of stimulus frequency OAEs. J Assoc Res Otolaryngol, 2003; 4(4): 521-40.

28. Mertes IB, Goodman SS. Within- and across-subject variability of repeated measurements of medial olivocochlear-induced changes in transient-evoked otoacoustic emissions. Ear Hear, 2016; 37(2): e72-e84.

29. Mishra SK, Lutman ME. Repeatability of click-evoked otoacoustic emission-based medial olivocochlear efferent assay. Ear Hear, 2013; 34(6): 789-98.

30. Graham RL, Hazell JWP. Contralateral suppression of transient evoked otoacoustic emissions: Intra-individual variability in tinnitus and normal subjects. Br J Audiol, 1994; 28(45): 235-45.

31. Stuart A, Cobb KM. Reliability of measures of transient evoked otoacoustic emissions with contralateral suppression. J Commun Disord, 2015; 58: 35-42.

32. Jedrzejczak WW, Pilka E, Olszewski L, Skarzynski H. Shortterm repeatability of contralateral suppression of transiently evoked otoaocutsic emissions: Preliminary results. J Hear Sci, 2016; 6(2): 51-57.

33. Guinan JJ. Olivocochlear efferent function: Issues regarding methods and the interpretation of results. Frontiers Systems Neurosci, 2014; 8: 142

34. Bonfils P, Piron JP, Uziel A, Pujol R. A correlative study of evoked otoacoustic emission properties and audiometric thresholds. Arch Otorhinolaryngol, 1988; 245(1): 53-56.

35. Probst R, Coats AC, Martin GK, Lonsbury-Martin BL. Spontaneous, click-, and toneburst-evoked otoacoustic emissions from normal ears. Hear Res, 1986; 21(3): 261-75.

36. de Boer J, Thornton ARD. Effect of subject task on contralateral suppression of click evoked otoacoustic emissions. Hear Res, 2007; 233(1): 117-23.

37. Harkrider AW, Bowers CD. Evidence for a cortically mediated release from inhibition in the human cochlea. J Am Acad Audiol, 2009; 20(3): 208-15.

38. Goldstein H. Multilevel Statistical Models. 2011, Chichester, West Sussex: Wiley. 
39. Snijders TAB, Bosker RJ. Multilevel Analysis: An introduction to basic and advanced multilevel modeling. 1999, London: SAGE

40. de Ceulaer G, Yperman M, Daemers K et al. Contralateral suppression of transient evoked otoacoustic emissions: Normative data for a clinical test set-up. Oto Neurotol, 2001; 22(3): 350-55.

41. Keppler H, Dhooge I, Maes L, D’haenens W, Bockstael A, Philips B et al. Transient-evoked and distortion product otoacoustic emissions: A short-term test-retest reliability study. Int J Audiol, 2010; 49(2): 99-109.

42. Kochanek KM, Sliwa LK, Puchacz K, Pilka A. Repeatability of transient-evoked otoacoustic emissions in young adults. Med Sci Monit, 2015; 21: 36-43.

43. Baradarnfar MH, Karamifar K, Mehrparvar AH, Mollasadeghi A, Gharavi M, Karimi G et al. Amplitude changes in otoacoustic emissions after exposure to industrial noise. Noise Health, 2012; 14(56): 28-31.
44. Kotylo M, Sliwinska-Kowalska P. Occupational exposure to noise decreases otoacoustic emission efferent suppression. Int J Audiol, 2002; 41(2): 113-19.

45. Sliwinska-Kowalska P, Kotylo M. Otoacoustic emissions in industrial hearing loss assessment. Noise Health, 2001; 3(12): 75-84.

46. McFadden D, Pasanen EG. Otoacoustic emissions and quinine sulfate. J Acoust Soc Am, 1994; 95(6): 3460-74.

47. Ueda H, Yamamoto Y, Yanagita N. Effect of aspirin on transiently evoked otoacoustic emissions in guinea pigs. ORL, 1996; 58(2): 61-67.

48. Gelfand SA, Piper N. Acoustic reflex thresholds in young and elderly subjects with normal hearing. J Acoust Soc Am, 1981; 69(1): 295-97.

49. Boothalingam S, Purcell DW. Influence of the stimulus presentation rate on medial olivocochlear system assays. J Acoust Soc Am, 2015; 137(2): 724-32. 